\title{
福島県, 会津盆地中西部地下における第四紀後期テフラの層序
}

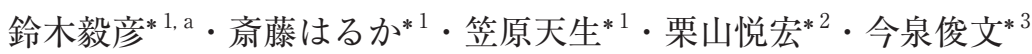

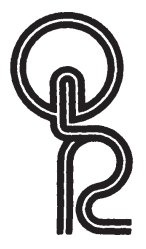

東北日本弧南部, 福島県会津坂下町で得た 3 本のボーリングコアからテフラを検出し, これら の認定を行い会津盆地中西部地下のテフラ層序を確立した。 また放射性炭素年代測定も実施し, それらの結果と合わせて盆地堆積物の年代と堆積速度を求めた. 地下約 $100 \mathrm{~m}$ 以浅の堆積物は シルト・泥炭・砂を主体とし，ところにより礫層やテフラを挟む. 認定したテフラは上位から Nm-NM (5.4ka), AT (30 ka), DKP (55 66 ka), Nm-KN, Ag-OK (<85.1 ka), TG (129ka), Sn-MT (180〜260 ka) である. 最長コアから得た堆積速度は, 地表/DKP 間で 0.46〜0.55 m/ kyrs, DKP/TG 間で 0.19〜0.23 m/kyrs である.

キーワード : ボーリングコア, 会津盆地, 姶良 Tn テフラ, 大山倉吉テフラ, 沼沢金山テフラ, 田頭テフラ

\section{I. は じめに}

東北日本の奥羽春梁山脈西方には, 会津盆地や山形盆 地など，周囲に比べて相対的沈降域である内陸盆地が南 北に連なる. これらの内陸盆地は, その東西縁が活断層 によって区切られる場合が多く(今泉, 1999 など), 内 陸盆地列南端に位置する会津盆地においても, 西縁に明 瞭な活断層である会津盆地西縁断層帯 (活断層研究会, 1991 ; 福島県, 2000, 2001, 2002 ; 地震調查研究推進 本部地震調査委員会 (以下, 推本と略), 2008) が存在 し, 会津盆地とその西側の会津盆地西縁丘陵との境を成 している(図 1).

中新世以降の会津盆地の発達史は, 鈴木ほか (1977) や山元ほか (2006) などにより議論されており, また会 津盆地西縁断層帯の最近数万年間の活動については推本 （2008）により報告されている. しかし中期更新世以降 の盆地発達史や断層帯の活動史の詳細は, それらを明ら かにする上で重要な盆地地下の堆積物の知見が限られる ために充分に明らかでない.

会津盆地の南西側には沼沢火山や砂子原カルデラなど の第四紀火山が存在し, それらを給源とする中期更新世
以降のテフラの知見が蓄積されてきた (山元, 1999, 2012 ; 鈴木ほか, 2004 など). これらテフラを盆地地下 の堆積物中に認定できれば堆積物深度と年代の関係が明 らかとなり, 盆地発達史や断層帯の活動史を復元する上 で有用な基礎資料となる。本研究では会津盆地西部会津 坂贸町において盆地内の既存ボーリングコア 1 本と新 規に掘削した 2 本のボーリングコアから多数のテフラ を検出し, それらを記載し, 対比した. また堆積物に含ま れる泥炭〜有機質シルトに対し放射性炭素年代測定を実 施した. これらの結果に基づき会津坂下町周辺地下にお けるテフラ層序を確立し, 盆地堆積物の深度と年代の関 係を明らかにした. 本論文ではこれらについて報告する.

\section{II. 調查地域とボーリング地点の概要}

調査地域周辺は, 会津盆地西縁断層帯を境界として, 西側の会津盆地西縁丘陵と東側の会津盆地からなる (図 1). 会津盆地西縁丘陵は標高 $300 \sim 500 \mathrm{~m}$ (盆地底との 比高が 150〜300 m) の南北に細長く伸びる丘陵である. 丘陵の東側には標高 $170 \sim 250 \mathrm{~m}$ の会津盆地が, 西側に は只見川の河谷を挟んで越後山地が広がる. 会津盆地西 縁丘陵と会津盆地の境には, 会津盆地西縁断層帯がほぼ

2014 年 1 月 15 日受付. 2015 年 11 月 28 日受理.

*1 首都大学東京大学院 都市環境科学研究科地理学教室 $\overline{1} 192-0397$ 八王子市南大沢 1-1.

*2 宇宙航空研究開発機構 $\overline{1} 182-8522$ 調布市深大寺東町 7-44-1.

$* 3$ 東北大学大学院理学研究科 $=980-8578$ 仙台市青葉区荒巻字青葉 6-3.

*a Corresponding author : suzukit@tmu.ac.jp 


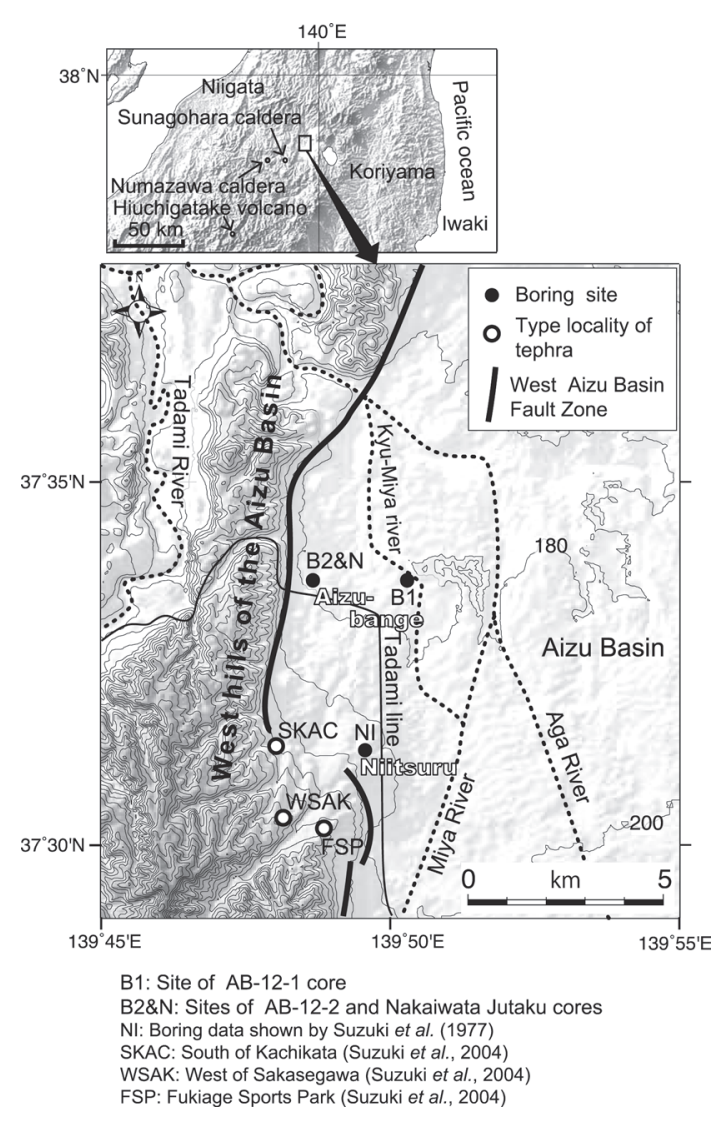

図 1 ボーリング地点および関連露頭の位置 院影図は国土地理院発行の $50 \mathrm{~m} \mathrm{DEM}$ を用いて作成，等高 線間隔は $20 \mathrm{~m}$. 断層位置は, 活断層研究会 (1991) より引用.

Fig. 1 Locations of drilling sites and related outcrops Relief map is created by using Digital Map 50 m Grid (Elevation) of Geospatial Information Authority of Japan (GSI). Contour line interval is $20 \mathrm{~m}$. Distribution of faults is after Research Group for Active Faults of Japan (1991).

南北方向に長さ約 $34 \mathrm{~km}$ で伸びており，西側隆起の逆 断層の活動により会津盆地西縁丘陵が盆地に対して相対 的に隆起し, 盆地と丘陵の地形境界を明暸にしている (推本, 2008).

調查地域とその周辺域の地質は山元 (1992) や山元ほ か (2006)によりまとめられており,それによれば中期 更新世以降の堆積物は下位から, 塔寺層, 段丘砂層, そ れらを覆うローム層や沖積層からなる。このうち塔寺層 は砂礫を主体とし, 会津盆地西縁丘陵東縁の幅 $1.5 \mathrm{~km}$ 以内の範囲に分布し, およそ南北走向で東側へ急傾斜 $\left(10 \sim 42^{\circ}\right)$ する. 塔寺層は会津盆地地下にも連続すると
され，会津美里町新鶴 (図 1) 付近の地下では, 深井戸 のボーリング資料から層厚 $40 \mathrm{~m}$ の沖積層の下位に本層 の存在が推定されている(鈴木ほか, 1977).

会津盆地西方の只見川沿いには, 沼沢火山と砂子原力 ルデラが存在し, 会津盆地西部における中期更新世以降 の重要な指標テフラの給源となっている. 両火山起源の テフラは, 山元 $(1999,2012)$ や鈴木ほか (2004)によ り層相・分布・記載岩石学的特徵が報告されているが, 名称や個々のテフラの対比・分布, 給源火山の推定に見 解の不一致がある.とくに鈴木ほか (2004) による後述 の田頭, 砂子原松ノ下, 砂子原迹瀬川の各テフラの認定 は, 山元 $(1999,2012)$ の報告と異なる点が多い. 本研 究では, テフラの模式地や試料採取層準が確実に保証で きることを理由に, 筆者等の一連の研究 (鈴木・早田, 1994 ; 鈴木ほか, 1995, 2004) によるテフラ名称を用い る. それらを以下に示すが, 合わせて山元 $(1999,2012)$ との違いについても触れておく.

沼沢火山起源のテフラは上位から沼沢沼沢湖テフラ $(\mathrm{Nm}-\mathrm{NM})$, 沼沢金山テフラ $(\mathrm{Nm}-\mathrm{KN})$, 沼沢芝原テ フラ $(\mathrm{Nm}-\mathrm{SB})$ の 3 枚であり，これらはそれぞれ山元 (2012) の沼沢沼沢湖テフラ $(\mathrm{Nm}-\mathrm{NK})$, 沼沢水沼テフ ラ $(\mathrm{Nm}-\mathrm{MZ})$, 沼沢芝原テフラ $(\mathrm{Nm}-\mathrm{SB})$ とほぼ同等で ある. 砂子原カルデラ起源テフラはすべて $\mathrm{Nm}-\mathrm{SB}$ の 下位にあり, 砂子原松ノ下テフラ $(\mathrm{Sn}-\mathrm{MT})$, 砂子原逆 瀬川テフラ $(\mathrm{Sn}-\mathrm{SK})$ の 2 枚, また砂子原カルデラ起源 の可能性が高いものとして田頭テフラ (TG) が認定され ている(鈴木ほか, 2004). Sn-MT は山元 (2012) の砂 子原一久保田テフラ $(\mathrm{Sn}-\mathrm{KB})$ や山元・須藤 (1996) の砂 子原-勝方テフラ $(\mathrm{Sn}-\mathrm{KC})$ に相当し, $\mathrm{Sn}-\mathrm{SK}$ は山元 (2012)によるものとほぼ同等である. TG は山元 (2012) の燧ヶ岳田頭テフラ $(\mathrm{Hu}-\mathrm{TG})$ とほぼ同じであるが, 会 津盆地西縁付近には分布しないとしており，鈴木ほ か (2004) がTG としたものは Sn-KB としている. ま た山元 (2012) は Hu-TG を尾瀬ヶ原北東に位置する燧 ケ岳火山起源としており, 給源火山の認定が鈴木ほか （2004）とは異なる.

\section{III. 対象コアと分析方法}

\section{1. 対象コアの概要}

今回対象とした 3 本のコアの採取地点は, いずれも 会津盆地中西部の会津坂下町に位置し, 会津西緣断層帯 の相対的低下側となる東側にある (図 2).2 本のコアは 2012 年 5 7 月に株式会社サンコアにより実施された オールコアボーリング (コア径 $68 \mathrm{~mm}$ )により得られた 


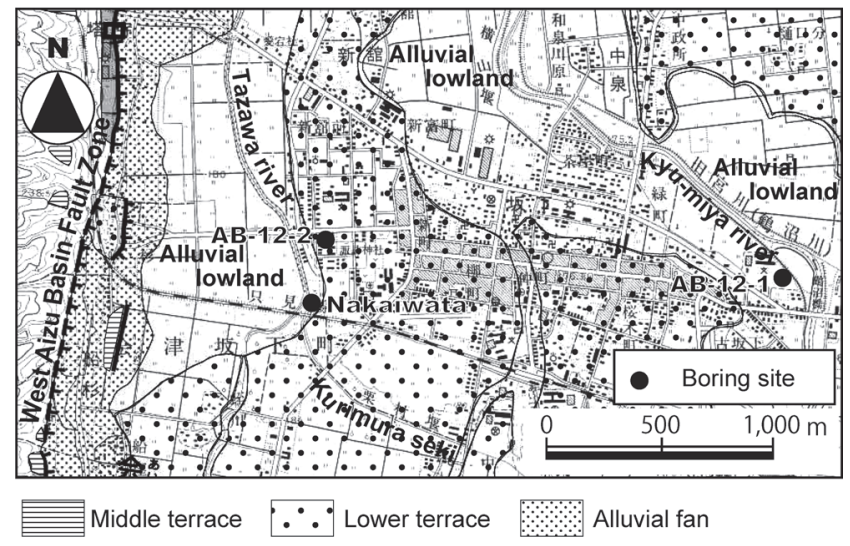

図 2 ボーリング地点位置詳細図 背景の地図と地形区分は都市圈活断層図「若松」(宮 内ほか, 2004)による。

Fig. 2 Detailed map of drilling sites Base map and landform classification are after the Active Fault Map in Urban Area "Wakamatsu" by Miyauchi et al. (2004).
ものであり, 以下, AB-12-1 コアと AB-12-2 コアと よぶ. 残りの 1 本は会津坂下町が保管していたもので あり, 中岩田住宅コアとよぶ.

\section{$\mathrm{AB}-12-1$ コア}

本コアは断層帯東方約 $2.5 \mathrm{~km}$ の標高 $177.32 \mathrm{~m}$ 地点

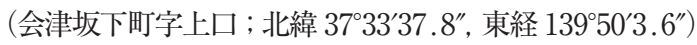
において掘削された，掘削地点は旧宮川（鶴沼川）左岸 河川敷に隣接する旧町立第一中学校 (現在, 坂下東小学 校) 敷地内であり, 河川敷との標高差はほぼ無い. 本地 点は柳田 (1979) では氾濫原, 宮内ほか (2004) では沖積 低地, 山元ほか (2006) では沖積層（礫・砂及び泥）の堆 積域とされている．掘削深度は $29 \mathrm{~m}$ である.

\section{AB-12-2 コア}

本コア掘削位置は断層帯東方約 $900 \mathrm{~m}$, 標高 179.09 $m$ 地点 (会津坂下町字中岩田 ; 北緯 37 $33^{\prime} 44.6^{\prime \prime}$, 東経 $\left.139^{\circ} 48^{\prime} 40.8^{\prime \prime}\right)$ であり, AB-12-1 コア掘削地の約 $2 \mathrm{~km}$ 西方である. 1976 年撮影の空中写真から判断すると周 囲は以前水田か畑地であったが，掘削時は住宅建設予定 の草地であった. 本地点は会津坂下町市街地の北東を北 流する旧宮川と市街地西側を北流する田沢川の間の微高 地西端付近に位置する。この微高地は柳田 (1979)によ れば三津合層 (Nm-NM の一部である沼沢火砕流堆積物 の二次堆積物) から構成される三津合面, また宮内ほか (2004) では下位段丘面 (図 2) とされ，山元ほか (2006) では礫・砂および泥からなる最低位段丘 I 堆積物（完新 世)の堆積域に相当する．掘削深度は $99.5 \mathrm{~m}$ である.

\section{中岩田住宅コア}

本コアは断層帯から東方約 $1 \mathrm{~km}$ の町営中岩田住宅 (会津坂下町中岩田) の建替事業にともなう地質調査に より，2003 年 7 月に掘削された. コア名はNo. 15B-10 であるが, 以後, 中岩田住宅コアとよぶ. 掘削地点は
AB-12-2 コアの南南西 $280 \mathrm{~m}$ に位置し, 標高 $180.52 \mathrm{~m}$ である (北緯 $37^{\circ} 33^{\prime} 35.05^{\prime \prime}$ ，東経 $139^{\circ} 48^{\prime} 38.01^{\prime \prime}$ )。旧宮 川などの比較的大きな河川からは $1 \mathrm{~km}$ 以上離れている が, 掘削地点の西側数 $10 \mathrm{~m}$ には旧宮川と合流する田沢 川が北流し, 田沢川に合流する栗村堰 (人工水路) とは $20 \mathrm{~m}$ 程度しか離れていない. またそれらの河床との比 高がほとんどなく沖積層が堆積する環境であり, 宮内ほ か (2004) では沖積低地と区分されている (図 2). 一方, 柳田 (1979) では三津合面, 山元ほか (2006) では礫・砂 及び泥からなる最低位段丘 I 堆積物 (完新世) の堆積域 とされている. ボーリングコアは, 総掘進長が $45.45 \mathrm{~m}$ であり, $1 \mathrm{~m}$ 毎の深度区間につき約 $50 \mathrm{~cm}$ 分が保存さ れていた。

\section{2. コア観察と分析}

AB-12-1 と AB-12-2 コアの観察は掘削後室内にて 実施した。最初に肉眼による層相観察を行い柱状図 (図 3）を作成した。一方, 中岩田住宅コアでは, 残されてい た $1 \mathrm{~m} こ ゙ と の$ 約 $50 \mathrm{~cm}$ 分について同様に層相観察し, 試料を欠く部分についてはコアと伴に保管されていた柱 状図を参考に柱状図を作成した。

コア中にテフラが認められた場合, 深度・層厚・粒 度・色調・堆積構造などを記載し試料を採取した。採取 テフラは, 層として認められるものに限らず, 砂層やシ ルト層中に塊状に濃集または散在する火山灰や軽石も含 む. 採取テフラ試料は粘土分がほぼ除去されるまで超音 波洗浄器で洗浄し, その後常温で風乾した. テフラ試料 は鉱物組合せと火山ガラスの形状を実体顕微鏡により明 らかにした. なお, 本研究では実体顕微鏡下での目測に よる定性的な含有鉱物種の把握に止めた. また火山ガラ スの形態分類は岸・宮脇 (1996) に基づく.

観察したテフラの中で層厚, 粒度, 岩片比などの特徴 


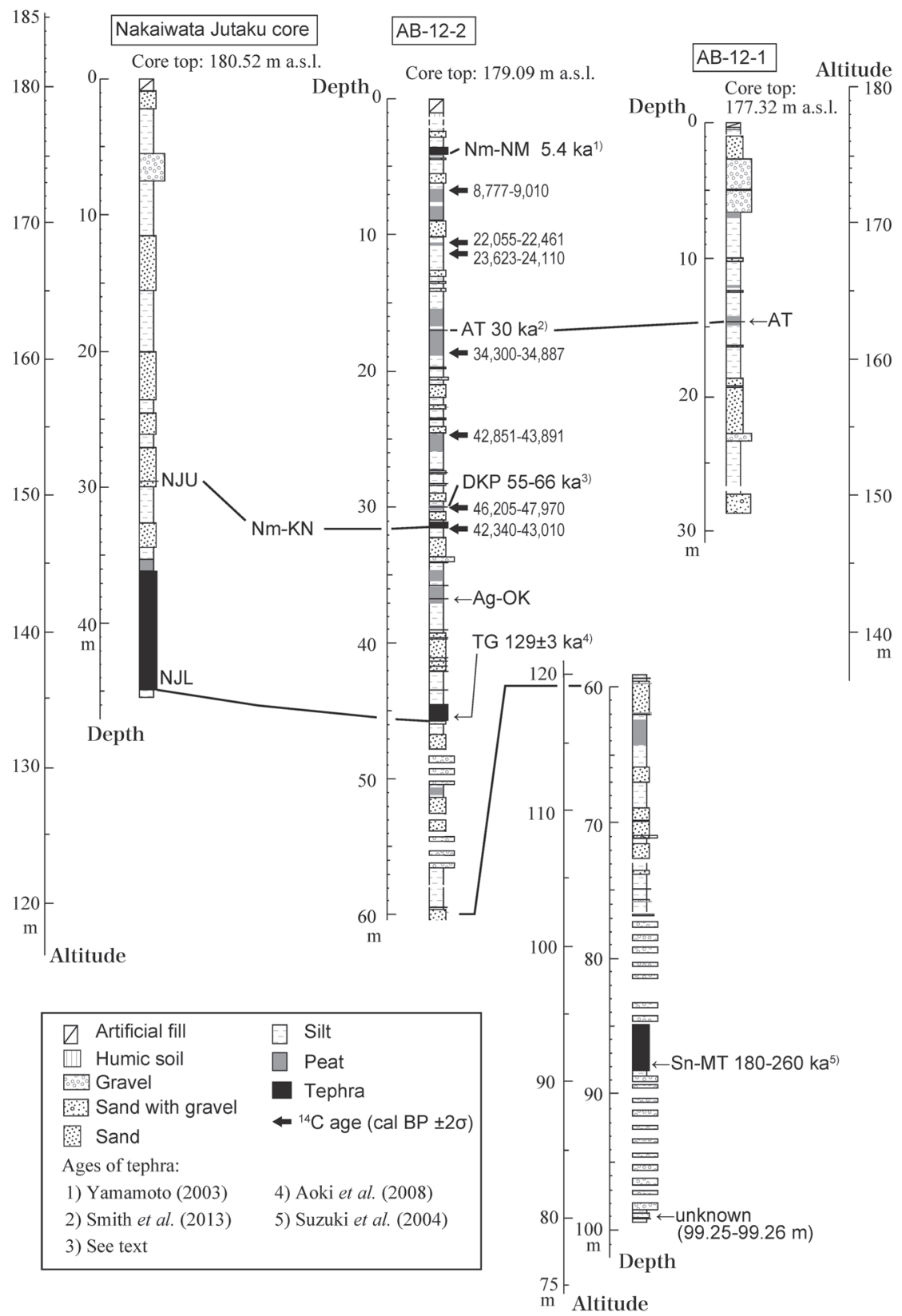

図 3 AB-12-1, AB-12-2 および中岩田住宅コアの柱状図 a.s.l. : 標高.

Fig. 3 Columnar sections of AB-12-1, AB-12-2, and Nakaiwata Jutaku cores a.s.l. : above sea level.

から広域に分布すると判断したものについては，火山ガ ラスと斑晶鉱物の屈折率を測定した。屈折率測定には首 都大学東京都市環境学部地理学教室所有の温度変化型屈
折率測定装置 (RIMS2000 : 京都フィッショントラック製) を用いて， 1 試料につき 25 粒子以上を測定した。 さら に11 テフラを対象に火山ガラスの主成分化学組成分析 
（EDS 分析）を行ったＥDS 分析は，上記教室所有の日 本電子製走査型電子顕微鏡 JSM-6390 および EDAX 社 製エネルギー分散型 X 線分析装置 EDAX-Genesis APEX2 を用いた. EDS 分析における測定条件は，加 速電圧 $15 \mathrm{kV}$, 試料電流 $0.6 \mathrm{nA}$ であり, 標準試料を用 いた ZAF 補正を行い，1 試料につき 13 以上のガラス 片を測定した．また，各試料の分析前後には姶良 Tn テ フラ (AT：町田・新井, 2003)の火山ガラスを標準試 料として測定し機器の安定性を確認している．本分析の 詳細と信頼性は Suzuki et al. (2014) に示されている.

コア掘削地点とテフラの供給源の候補との位置関係お よび，上記の方法により得られたデー夕をもとに，広域 テフラについては町田・新井 (2003), 東北南部に局地 的に分布するテフラについては鈴木ほか $(1995,2004)$ や鈴木・早田 (1994) に示されたテフラの諸特性を参考 にして，対比候補テフラを選定した，対比候補テフラ は，模式地での層相観察と試料採取を行い，同様な分析 を行った (表 1)。対比の検討は, 層位, 岩相, 斑晶鉱物 組合せ, 火山ガラスや斑晶鉱物の屈折率, 火山ガラスの 主成分化学組成に基づき行ったが, 屈折率と主成分化学 組成の分析は対象となる構成粒子が存在する場合のみに 実施した，対比候補テフラの模式試料は， Nm-NM と $\mathrm{Nm}-\mathrm{KN}$ がそれぞれ福島県金山町大栗山西方，同三島 町早戸湯ノ平 (鈴木・早田, 1994), TG と Sn-MT が 新鶴村佐賀瀬川西方 (図 1 の WSAK), Sn-SK が会津 坂下町勝妿南方 (図 1 の SKAC) (鈴木ほか, 2004) で採 取したものを用いた。

ところでこの 4 テフラに含まれる火山ガラスの主成分 化学組成 (表 1) は鈴木・早田 (1994) や鈴木ほか (2004) に示されているそれらと若干異なる. その理由は測定機 器の違い (以前は日本電子製走査型電子顕微鏡 JSM5200 および同社製エネルギー分散型 X 線分析装置 JED-2001 を使用) に由来し，従来の測定では測定の再 現性は保たれていたものの, $\mathrm{CaO}$ 含有量が他の研究機 関の測定值に比較して系統的に低いなどの問題があった (Suzuki, 1996)。今回得た測定値は，著者らの従来の測 定値に比べてより信頼性が高い分析方法 (Suzuki et al., 2014）で得られたものである.

AB-12-2 コア中の 7 層準の泥炭ないしは有機質シル 卜に対して ${ }^{14} \mathrm{C}$ 年代測定を行った (図 3, 表 2)。測定は 株式会社パレオ・ラボにより加速器質量分析法で実施さ れ, 試料調製後, 加速器質量分析計 (コンパクト AMS : $\mathrm{NEC}$ 製 $1.5 \mathrm{SDH}$ ）により測定された。得られた ${ }^{14} \mathrm{C}$ 濃 度について同位体分別効果の補正を行った後, ${ }^{14} \mathrm{C}$ 年代
と暦年代が算出された. 暦年較正ではIntCal13 (Reimer et al., 2013）の較正曲線デー夕に基づき OxCal4.1 （Bronk Ramsey, 2009）を使用した.

\section{IV． 堆積物とテフラの記載}

\section{1. $\mathrm{AB}-12-1$ コア}

本コアで確認した堆積物は, 深度 $0 \sim 0.33 \mathrm{~m}$ の盛土, 深度 $0.33 \sim 0.57 \mathrm{~m}$ の土壤層を除き, それ以深はシルト, 泥炭, 砂, 磁からなる (図 3). 深度 $0.57 \sim 0.74 \mathrm{~m}$ が灰〜 褐色シルト層, 深度 $0.74 \sim 2.70 \mathrm{~m}$ が粗粒砂・中粒砂を 主とする砂層, その下位は最大径約 $4 \mathrm{~cm}$ の中礫サイズ の亜円礫層（深度 $2.70 \sim 6.60 \mathrm{~m}$ ) である．その下位は, 明瞭な境界を隔てて深度 $18.81 \mathrm{~m}$ までおもにシルト〜 有機質シルトからなり, 部分的に層厚 $10 \mathrm{~cm}$ 以下の泥炭 層を含む．深度 $18.81 〜 22.87 \mathrm{~m}$ は粗粒砂を主とする砂 層からなり, 部分的に層厚 $15 \mathrm{~cm}$ 以下の細礫層を挟む. 深度 22.87 23. $42 \mathrm{~m}$ では再び中碟サイズの亜円鿬層 （最大径約 $4 \mathrm{~cm} ）$ となる. その下位は明瞭な境界を隔て て深度 $26.82 \mathrm{~m}$ までおもにシルト〜有機質シルトからな る. その下位は $29 \mathrm{~cm}$ のコア久損があり, 深度 $27.11 〜$ $28.74 \mathrm{~m}$ (コア最深部) は中鿬サイズの亜円礫を含む粗 粒砂層である. 上記の様に, $\mathrm{AB}-12-1$ コアでは 3 層準 で礫層ないしは鿬を含む粗粒砂層が認められ，その間は 主にシルト, 泥炭, 砂から構成される.

テフラは深度 14.68〜 $14.72 \mathrm{~m}$ に 1 枚を検出した. 本 テフラは約 $50 \mathrm{~cm}$ の泥炭層に挟在される層厚 $4 \mathrm{~cm}$ の塊 状の淘汰の良い中粒砂サイズの白色ガラス質火山灰層で ある. 本テフラは上下の泥炭層とは明瞭な境界で接し, 平均粒径 $0.2 \sim 0.4 \mathrm{~mm}$, 最大粒径 $0.6 \mathrm{~mm}$ の無色透明 なバブルウォール型の火山ガラスからなる。 その屈折 率は $\mathrm{n}=1.499 \sim 1.500$, 主成分化学組成は平均重量\% (以下, $\mathrm{wt} \%$ ) で, $\mathrm{SiO}_{2}: 78.0 \mathrm{wt} \%, \mathrm{Al}_{2} \mathrm{O}_{3}: 12.4 \mathrm{wt} \%$, $\mathrm{Na}_{2} \mathrm{O}: 3.4 \mathrm{wt} \%, \mathrm{~K}_{2} \mathrm{O}: 3.3 \mathrm{wt} \%$ である(表 1).

\section{2. $\mathrm{AB}-12-2$ コア}

本コアは, 深度 $0 \sim 1.08 \mathrm{~m}$ が盛土であり, その下位 は層厚約 $32 \mathrm{~cm}$ の土壤層で, 深度 $76.81 \mathrm{~m}$ まで全体的 に細粒堆積物が卓越する。 それ以深はコア基底まで礫層 が卓越し, $76.81 \sim 84.74 \mathrm{~m}, 88.76 \sim 98.59 \mathrm{~m}$ に最大径 $7 \mathrm{~cm}$ 程度の亜円碩を含む礫層が存在する (図 3 )。深度 $76.81 \mathrm{~m}$ 以浅でも深度 $33.69 \sim 34.04 \mathrm{~m}, 48.33 \sim 50.46$ $\mathrm{m}, 54.49 \sim 56.47 \mathrm{~m}$ に最大径 3〜 $4 \mathrm{~cm}$ の中礫サイズの 亜円碟からなる鿬層があり, いずれも上位に層厚 $1 \sim 3 \mathrm{~m}$ の平行葉理が発達した砂層や砂・シルト互層をともな う。これらを除くと深度 $76.81 \mathrm{~m}$ までは泥炭層, 砂層, 


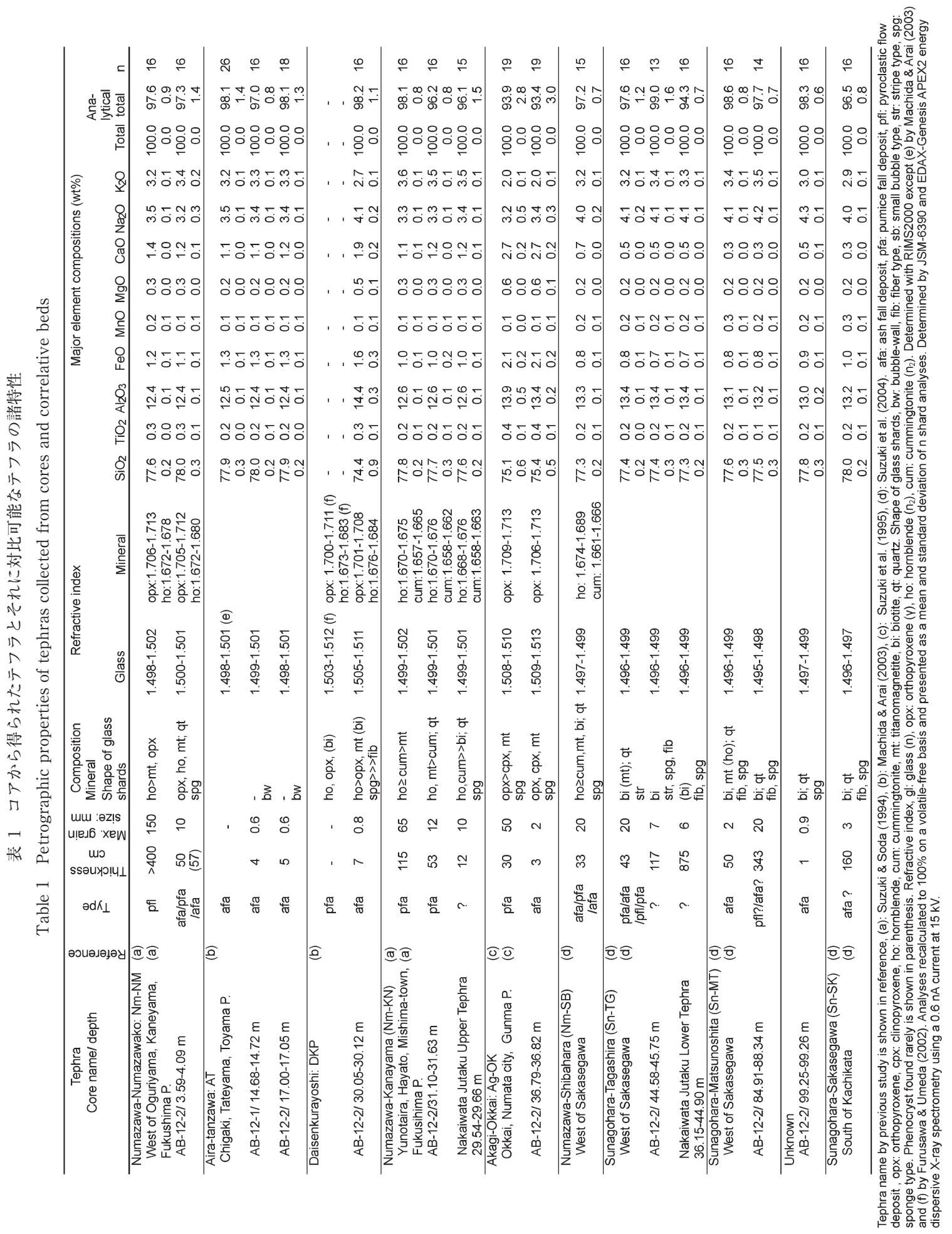


表 2 AB-12-2 コアから得られた泥炭〜有機質シルトの ${ }^{14} \mathrm{C}$ 年代測定值

Table $2{ }^{14} \mathrm{C}$ dates of peat and organic silt collected from the $\mathrm{AB}-12-2$ core

\begin{tabular}{ccccccc}
\hline \hline $\begin{array}{c}\text { Sample } \\
\text { number }\end{array}$ & $\begin{array}{c}\text { Depth } \\
(\mathrm{m})\end{array}$ & $\begin{array}{c}\text { Measured }{ }^{14} \mathrm{C} \\
\text { age } \\
(\mathrm{yrs} \mathrm{BP})\end{array}$ & $\begin{array}{c}\delta^{13} \mathrm{C} \\
(\%)\end{array}$ & $\begin{array}{c}\text { Conventional age } \\
{ }^{14} \mathrm{C} \text { age }(\mathrm{yrs} \mathrm{BP})\end{array}$ & $\begin{array}{c}\text { Calibrated age } \\
2 \sigma(\text { cal BP) }\end{array}$ & $\begin{array}{c}\text { Laboratory } \\
\text { code }\end{array}$ \\
\hline AB-12-2-A & $6.73-6.75$ & $8024 \pm 27$ & $-18.20 \pm 0.20$ & $8025 \pm 25$ & $\begin{array}{c}8777-9010 \\
(67.0 \%)\end{array}$ & PLD-26144 \\
AB-12-2-B & $10.72-10.74$ & $18408 \pm 53$ & $-31.06 \pm 0.20$ & $18410 \pm 50$ & $22055-22461$ & PLD-26145 \\
AB-12-2-C & $11.44-11.46$ & $19834 \pm 73$ & $-30.20 \pm 0.33$ & $19830 \pm 70$ & $23623-24110$ & PLD-26146 \\
AB-12-2-D & $18.65-18.68$ & $30667 \pm 118$ & $-29.46 \pm 0.15$ & $30670 \pm 120$ & $34300-34887$ & PLD-26147 \\
AB-12-2-E & $24.71-24.73$ & $39654 \pm 258$ & $-30.34 \pm 0.17$ & $39650 \pm 260$ & $42851-43891$ & PLD-26148 \\
AB-12-2-F & $30.27-30.29$ & $43852 \pm 330$ & $-29.81 \pm 0.22$ & $43850 \pm 330$ & $46205-47970$ & PLD-26149 \\
AB-12-2-G & $31.63-31.65$ & $38714 \pm 203$ & $-29.48 \pm 0.20$ & $38710 \pm 200$ & $42340-43010$ & PLD-26150 \\
\hline \hline
\end{tabular}

テフラ層を頻繁に挟むシルト層が卓越する．顕著な泥炭 層は $64.29 \mathrm{~m}$ 以浅で 8 層準認められる (図 3). AB12-2 コアで認定した 8 枚のテフラを以下に産出する深 度ごとに記載する。

\section{深度 3.59 4.09 m}

層厚少なくとも $50 \mathrm{~cm}$ のテフラ層で, 下位の泥炭層と は明瞭な境界で接する. 上部は $7 \mathrm{~cm}$ のコア欠損がある ため上位の火山灰質砂質シルト層との境界は観察でき ず，層厚が最大で $57 \mathrm{~cm}$ の可能性がある. テフラ層は, 下部が層厚 $9 \mathrm{~cm}$ の極粗粒砂サイズの軽石質火山灰 層 (平均粒径約 $1 \mathrm{~mm}$, 最大粒径約 $5 \mathrm{~mm}$ ), $3 \mathrm{~cm}$ の欠損 を隔て, 中部は層厚 $6 \mathrm{~cm}$ の軽石層 (平均粒径約 $2 \sim 6$ $\mathrm{mm}$, 最大粒径 $10 \mathrm{~mm}$ ), 上部は層厚 $32 \mathrm{~cm}$ の極細粒砂 サイズの淡桃色火山灰層 (平均粒径約 $0.1 \mathrm{~mm}$, 最大粒 径 $0.3 \mathrm{~mm}$ ) からなる. 中部の軽石層は発泡の悪い最大 粒径 $1 \mathrm{~cm}$ の青色ラピリや白色軽石からなり，基質を欠 く．上下の火山灰層は軽石粒子などを含まず淘汰がよ い.下部の火山死層と中部の軽石層に含まれる主な斑晶 鉱物は斜方輝石，ホルンブレンド，チタン磁鉄鉱，石英 である. 斜方輝石とホルンブレンドの屈折率はそれぞれ $\gamma=1.705 \sim 1.712, \mathrm{n}_{2}=1.672 \sim 1.680$ である(表 1 ). ま た上部の火山灰層は細粒なスポンジ状軽石型火山ガラス を多く含み，その主成分化学組成は, $\mathrm{SiO}_{2}: 78.0 \mathrm{wt} \%$, $\mathrm{Al}_{2} \mathrm{O}_{3}: 12.4$ wt $\%, \mathrm{Na}_{2} \mathrm{O}: 3.2$ wt\%, $\mathrm{K}_{2} \mathrm{O}: 3.4$ wt\% である。

\section{深度 $17.00 \sim 17.05 \mathrm{~m}$}

泥炭層に挟在される層厚 $5 \mathrm{~cm}$ の塊状で淘汰の良い中 粒砂サイズの白色ガラス質火山灰層 (平均粒径 $0.2 \sim 0.4$ $\mathrm{mm}$ ，最大粒径 $0.6 \mathrm{~mm}$ ) である. 本テフラは上下の泥 炭層とは明瞭な境界で接し, 最大粒径 $0.6 \mathrm{~mm}$ の無色 透明なバブルウォール型の火山ガラスを主とする. 火山 ガラスの屈折率は $\mathrm{n}=1.498 \sim 1.501$, 主成分化学組成 は, $\mathrm{SiO}_{2}: 77.9$ wt\%, $\mathrm{Al}_{2} \mathrm{O}_{3}: 12.4$ wt\%, $\mathrm{Na}_{2} \mathrm{O}: 3.4$ wt\%, $\mathrm{K}_{2} \mathrm{O}: 3.3 \mathrm{wt} \%$ である (表 1).

\section{深度 $30.05 \sim 30.12 \mathrm{~m}$}

泥炭層中に最大で層厚 $7 \mathrm{~cm}$ の塊状の白色ガラス質火 山灰層が挟まる，下位の泥炭層とは明瞭な境界で接する が，上位の泥炭層との境界は漸移的で数 $\mathrm{cm}$ 程度の凹凸 がある. 本テフラはスポンジ状軽石型の火山ガラス (粒 径 $0.8 \mathrm{~mm}$ 以下), ホルンブレンド, 斜方輝石, チタン磁 鉄鉱, 微量の黒雲母からなり, 斜方輝石は (100) 面が発 達した特徴をもつ. 火山ガラスの屈折率は $\mathrm{n}=1.505$ ～ 1.511，ホルンブレンドと斜方輝石のそれは，それぞれ $\mathrm{n}_{2}=1.676 \sim 1.684, \gamma=1.701 \sim 1.708$ である. 火山ガラ スの主成分化学組成は, $\mathrm{SiO}_{2}: 74.4 \mathrm{wt} \%, \mathrm{Al}_{2} \mathrm{O}_{3}: 14.4$ wt\%, $\mathrm{Na}_{2} \mathrm{O}: 4.1$ wt\%, $\mathrm{K}_{2} \mathrm{O}: 2.7$ wt\% であり, $\mathrm{SiO}_{2}$ の組成幅が今回検討したテフラの中では最も広い (図 4 , 表 1).

\section{深度 $31.10 \sim 31.63 \mathrm{~m}$}

上記の白色ガラス質火山灰層の下位約 $1 \mathrm{~m}$ の深度 $31.10 \sim 31.63 \mathrm{~m}$ では, 層厚 $53 \mathrm{~cm}$ の軽石層 (平均粒径 3 $8 \mathrm{~mm}$, 最大粒径 $12 \mathrm{~mm}$ ) が観察された. 上下のシル 卜層とは明膫な境界で接する，本軽石層には明膫な成層 構造はなく逆級化する。.また基質が認められず淘汰がよ い．軽石は円磨度が低く亜角～角礫を呈する．本テフラ は斑晶鉱物に富んだ発泡の悪い白〜灰色軽石を主体と し，軽石はホルンブレンド，チタン磁鉄鉱，石英のほか 微量のカミングトン閃石を含む. ホルンブレンド，カミ ングトン閃石, 火山ガラスの屈折率は, それぞれ $\mathrm{n}_{2}=$ $1.670 \sim 1.676, \mathrm{n}_{2}=1.658 \sim 1.662, \mathrm{n}=1.499 \sim 1.501$ である. 火山ガラスの主成分化学組成は, $\mathrm{SiO}_{2}: 77.7$ wt\%, $\mathrm{Al}_{2} \mathrm{O}_{3}: 12.6 \mathrm{wt} \%, \mathrm{Na}_{2} \mathrm{O}: 3.3 \mathrm{wt} \%, \mathrm{~K}_{2} \mathrm{O}: 3.5$ $\mathrm{wt} \%$ である(表 1).

\section{深度 $36.79 \sim 36.82 \mathrm{~m}$}

層厚 $3 \mathrm{~cm}$ の粗粒砂サイズ (平均粒径 0.4 1.0 $\mathrm{mm}$, 最大粒径 $2 \mathrm{~mm}$ )の淘汰良好な軽石質火山灰層である. 

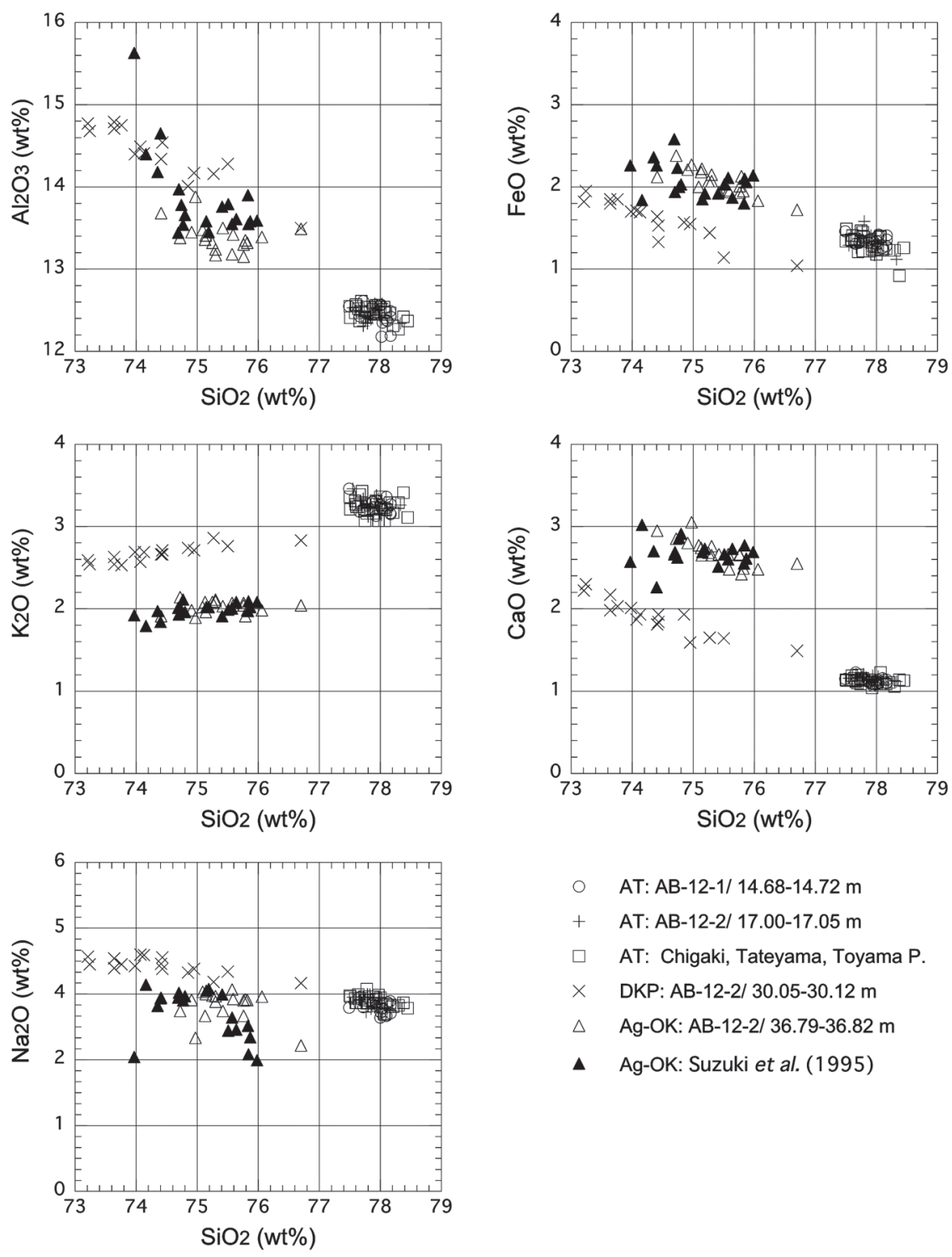

図 4 AT, DKP および Ag-OK の火山ガラス主成分化学組成

Fig. 4 Chemical compositions of glass shards in AT, DKP, and Ag-OK tephras

本層は上下の泥炭層と明瞭な境界で接するが，上位の泥 炭層中には本層に由来すると考えられる火山灰が $5 \mathrm{~cm}$ にわたり散在する。本火山灰層はスポンジ状軽石型火山 ガラス, 斜方輝石, 単斜輝石, チタン磁鉄鉱からなり, 火山ガラスと斜方輝石の屈折率はそれぞれ, $\mathrm{n}=1.509$ $1.513, \gamma=1.706 \sim 1.713$ である. 火山ガラスの主成分化 学組成は, $\mathrm{SiO}_{2}: 75.4 \mathrm{wt} \%, \mathrm{Al}_{2} \mathrm{O}_{3}: 13.4 \mathrm{wt} \%, \mathrm{Na}_{2} \mathrm{O}$ : $3.4 \mathrm{wt} \%, \mathrm{~K}_{2} \mathrm{O}: 2.0 \mathrm{wt} \%$ である (図 4, 表 1).

\section{深度 $44.58 \sim 45.75 \mathrm{~m}$}

層厚 $117 \mathrm{~cm}$ の白〜青灰色を呈する火山灰層である. 下位の粗粒砂層とは明暸な境界な境界で接し，上位の有 機質シルト層とも比較的明瞭な境界で接するが，この有 機質シルト層は本火山灰層上端から約 $55 \mathrm{~cm}$ にかけて は火山灰質である. 不明膫であるが, 数 $\mathrm{cm}$ から $10 \mathrm{~cm}$ 毎に粒径変化が認められ, 粗粒な部分で粗粒砂サイズ, 細粒な部分で細粒砂サイズである. $45.35 \mathrm{~m}$ 付近では粒 
径約 $7 \mathrm{~mm}$ の軽石が含まれていたが，これを除くと火 山唩サイズの軽石は検出されなかった，全体的に平行型 の火山ガラスを多く含み, スポンジ状や纎維状の火山ガ ラスもみられ，わずかに黒雲母も含む．火山ガラスの屈 折率は $\mathrm{n}=1.496 \sim 1.499$ ，またその主成分化学組成は, $\mathrm{SiO}_{2}: 77.4$ wt\%, $\mathrm{Al}_{2} \mathrm{O}_{3}: 13.4$ wt\%, $\mathrm{Na}_{2} \mathrm{O}: 4.1 \mathrm{wt} \%$, $\mathrm{K}_{2} \mathrm{O}: 3.4 \mathrm{wt} \%$ である(図 5, 表 1 ).

\section{深度 $84.91 \sim 88.34 \mathrm{~m}$}

層厚 $3.43 \mathrm{~m}$ のテフラ層で，下位の有機質シルト層と
の境界をなす本テフラ層基底は平坦で明瞭であるが，上 端は $17 \mathrm{~cm}$ 分のコア欠損があるため上位層との境界が 確認できず，欠損部の上位は磁層である. 本テフラ最下 部の $19 \mathrm{~cm}$ は細粒砂サイズから粗粒砂サイズの成層し た火山灰からなり全体的に逆級化し, 数 $\mathrm{mm}$ の亜角〜 角礫状の軽石を含む上部は淘汰が悪い．また下位層をわ ずかに削り込む斜交層理をもつ，その直上は弱い平行葉 理をもつ層厚 $13 \mathrm{~cm}$ の淘汰のよい粗粒砂サイズの火山 灰層 (平均粒径 $0.3 \sim 0.8 \mathrm{~mm}$, 最大粒径 $2 \mathrm{~mm}$ ) である.
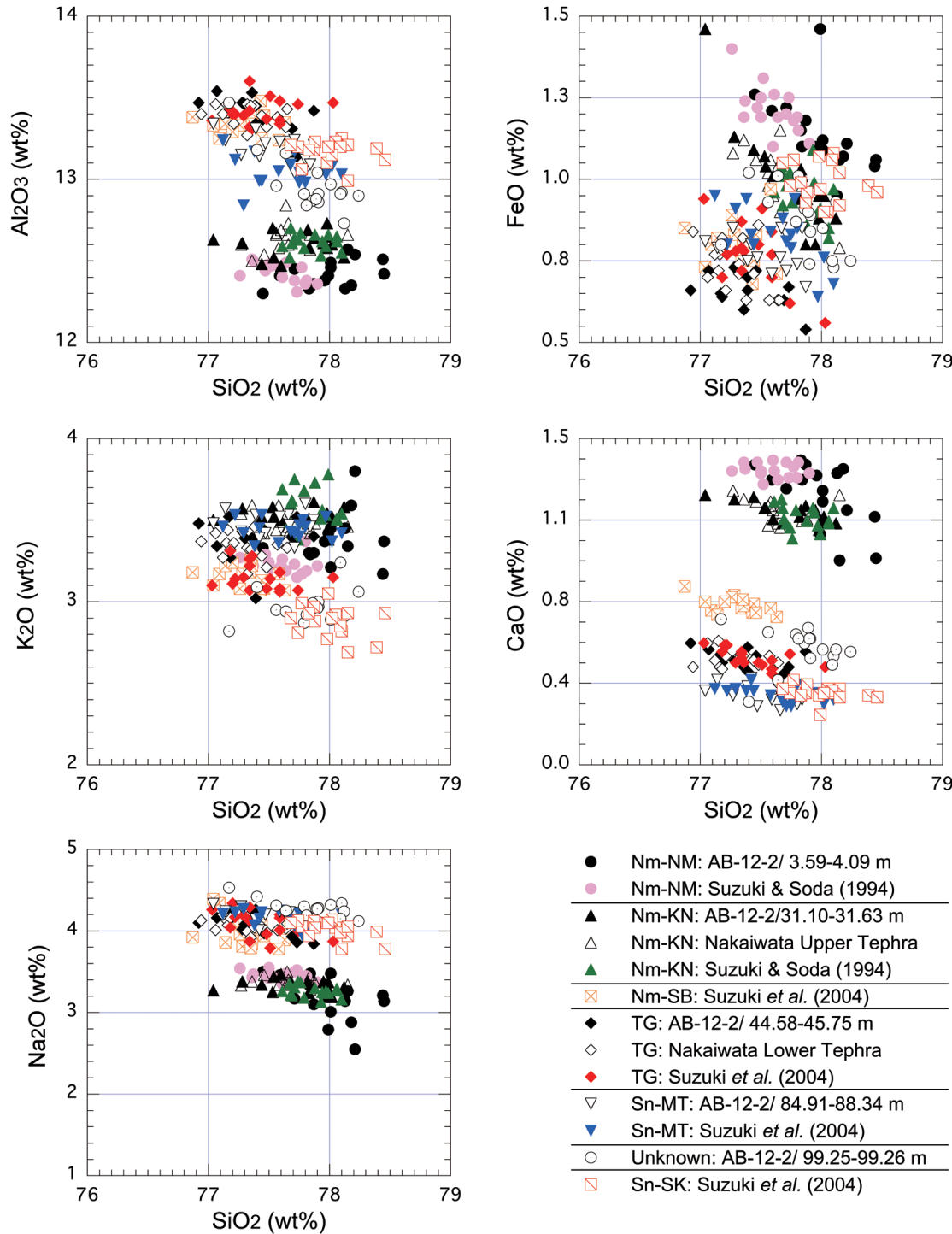

図 5 沼沢・砂子原カルデラ起源テフラの火山ガラスの主成分化学組成

Fig. 5 Chemical compositions of glass shards in tephras derived from Numazawa and Sunagohara calderas 
その上位の約 $3.1 \mathrm{~m}$ は最下部に $2 \mathrm{~cm}$ の白色軽石が 1 粒 子検出されたことを除くと, 大半が粒径 $7 \mathrm{~mm}$ 以下の亜 角〜角礫状の白色軽石が散在し, 極粗粒砂サイズの火山 灰からなる基質が卓越する．中部の 86.00 ～ $86.52 \mathrm{~m}$ 付 近は軽石にそしく, 基質がシルトサイズの火山灰である. 本テフラは瀻維状とスポンジ状の軽石型火山ガラス，黒 雲母，石英を含む．火山ガラスの屈折率は $\mathrm{n}=1.495$ 1.498, またその主成分化学組成は, $\mathrm{SiO}_{2}: 77.5 \mathrm{wt} \%$, $\mathrm{Al}_{2} \mathrm{O}_{3}: 13.2$ wt $\%, \mathrm{Na}_{2} \mathrm{O}: 4.2 \mathrm{wt} \%, \mathrm{~K}_{2} \mathrm{O}: 3.5 \mathrm{wt} \%$ で ある(図 5 , 表 1 ).

\section{深度 $99.25 \sim 99.26 \mathrm{~m}$}

層厚 $1 \mathrm{~cm}$ の中粒砂サイズの白色ガラス質火山灰層 （平均粒径 $0.2 \sim 0.6 \mathrm{~mm}$, 最大粒径 $0.9 \mathrm{~mm}$ ）である. 本層は下位の泥炭層, 上位の火山灰質シルト層とは明瞭 な境界で接する．本テフラは，スポンジ状軽石型火山ガ ラス, 黒雲母, 石英を含む. 火山ガラスの屈折率は $\mathrm{n}=$ 1.497〜1.499, また主成分化学組成は, $\mathrm{SiO}_{2}: 77.8$ wt\%, $\mathrm{Al}_{2} \mathrm{O}_{3}: 13.0$ wt\%, $\mathrm{Na}_{2} \mathrm{O}: 4.3 \mathrm{wt} \%, \mathrm{~K}_{2} \mathrm{O}: 3.0$ wt\% である (図 5 , 表 1 ).

\section{3. 中岩田住宅コア}

ボーリング掘削時の柱状図によると, 中岩田住宅コア では, 深度 $0.80 \mathrm{~m}$ までの盛土を除くと, 掘削深度の $45.45 \mathrm{~m}$ までは砂，シルト，砂礫，腐植土からなる（図 3). 大半はシルト〜有機質シルトないしは細砂と記載さ れている部分からなり, 砂礫層は深度 $5.60 \sim 7.30 \mathrm{~m}$ に のみ存在する．柱状図でシルトとされている部位は腐植 物を多く含み，有機質シルトとされている部分には多量 の腐植物が認められ泥炭層の薄層も挟まれている，細砂 とされている部分は部分的に細啋や腐植物を含むが，堆 積構造は試料の保存状態が悪く不明である. 深度 5.60 $7.30 \mathrm{~m}$ の砂砂層は径 $4 \mathrm{~cm}$ 程度の角〜亜円礫を主体と し，基質は細粒砂からなる．砂やシルトの部分で柱状図 に凝灰質と記された部位は 29.00 29.95 m と 36.15 $44.90 \mathrm{~m}$ にあるが，明確に火山灰や軽石と記載された部 位はない.しかし, 本研究でのコア観察により, 本コア に含まれる 2 枚のテフラ層を新たに記載した。これら を中岩田住宅上部テフラ $(\mathrm{NJU})$ ， 同下部テフラ $(\mathrm{NJL})$ とよぶ.

\section{中岩田住宅上部テフラ (NJU)}

$\mathrm{NJU}$ は微細砂と記載された砂層中に挟在し, 深度 $29.54 \sim 29.66 \mathrm{~m}$ に $12 \mathrm{~cm}$ の厚さで産出する.コア試料 の乾燥と攪乱により上下の堆積物との境界やその特徵は 不明であるが，本テフラの上部は斑晶が目立つ白色軽石 (平均粒径 $2 \sim 6 \mathrm{~mm}$, 最大粒径 $1 \mathrm{~cm}$ ) を含む．また正級
化するようにもみえるが，未固結なためコア採取中に攪 乱している可能性もあり本来の層相は不明である，本層 上位の砂層中に軽石が散在し，本層下位からは軽石が観 察されない. NJUの鉱物組合せは, ホルンブレンド, カ ミングトン閃石，黒雲母，石英である (表 1 )。また，ス ポンジ状の火山ガラスを多量に含み, その屈折率は $\mathrm{n}=$ 1.499 1.501 を示す. ホルンブレンド，カミングトン 閃石の屈折率は, $\mathrm{n}_{2}=1.668 \sim 1.676, \mathrm{n}_{2}=1.658 \sim 1.663$ である. 火山ガラスの主成分化学租組成は $\mathrm{SiO}_{2}: 77.6$ wt $\%, \quad \mathrm{Al}_{2} \mathrm{O}_{3}: 12.6 \mathrm{wt} \%, \quad \mathrm{Na}_{2} \mathrm{O}: 3.4 \mathrm{wt} \%, \mathrm{~K}_{2} \mathrm{O}: 3.5$ $\mathrm{wt} \%$ である.

\section{中岩田住宅下部テフラ (NJL)}

NJL は, $8.75 \mathrm{~m}$ の厚さで深度 $36.15 \sim 44.90 \mathrm{~m}$ に位 置する. 本テフラ基底は, 下位にある硬い有機質シルト 層と明瞭な境界をなし，上位は層厚約 $1 \mathrm{~m}$ の泥炭層に 覆われるが，その境界の状態は不明である．NJLの最 下部 $15 \mathrm{~cm}$ は淘汰のよい白色軽石 (平均粒径 2 $4 \mathrm{~mm}$, 最大粒径 $6 \mathrm{~mm}$ ）からなる塊状の軽石層であり，含まれ る軽石は亜角〜角礫状である，一方，本テフラ上部の $8.6 \mathrm{~m}$ は, 残されたコア試料 $(1 \mathrm{~m}$ 毎の深度区間につき 約 $50 \mathrm{~cm}$ 分) が主に軽石を含まない火山灰質の細粒物か らなるため便宜的に単一のテフラとして扱うが，時間間 隙を含まない 1 枚のテフラ層ではない，すなわち掘削 時の柱状図によれば上位から，均質な凝灰質シルト混じ り細砂 (層厚 $1.35 \mathrm{~m}$ ), 複数のシルト薄層を挟む凝灰質 微細砂 (層厚 $2 \mathrm{~m}$ ), 所々 細砂を含吉凝灰質シルト (層厚 $1 \mathrm{~m})$, そして部分的にシルト質細砂, 径 $1 \mathrm{~cm}$ 以下の砂, 極薄い砂砂層が含まれる凝灰質細砂 (層厚 $4.25 \mathrm{~m}$ ) であ る.

NJL 最下部の軽石は黒雲母を少量含む以外の斑晶鉱 物はほとんど認められない。また多量に含まれる繊維状 とスポンジ状の火山ガラスの屈折率は $\mathrm{n}=1.496$ 1.499 と低い值を示す (表 1). 火山ガラスの主成分化学 租組成は $\mathrm{SiO}_{2}: 77.3 \mathrm{wt} \%, \mathrm{Al}_{2} \mathrm{O}_{3}: 13.4 \mathrm{wt} \%, \mathrm{Na}_{2} \mathrm{O}$ : $4.1 \mathrm{wt} \%, \mathrm{~K}_{2} \mathrm{O}: 3.3 \mathrm{wt} \%$ である(図 5 , 表 1).

\section{V. ${ }^{14} \mathrm{C}$ 年代測定結果}

AB-12-2 コア中の 7 層準の泥炭ないしは有機質シル 卜から ${ }^{14} \mathrm{C}$ 年代測定值を得た (図 3, 表 2).上位から較正 年代 $(2 \sigma)$ を示すと $8,777 \sim 9,010 \mathrm{cal} \mathrm{BP}($ 深度 6.73〜 $6.75 \mathrm{~m}), 22,055 \sim 22,461 \mathrm{cal}$ BP (深度 $10.72 \sim 10.74$ $\mathrm{m}), 23,623 \sim 24,110 \mathrm{cal} \mathrm{BP}$ (深度 $11.44 \sim 11.46 \mathrm{~m}$ ), $34,300 \sim 34,887 \mathrm{cal} \mathrm{BP}$ (深度 $18.65 \sim 18.68 \mathrm{~m}$ ) , 42,851 $\sim 43,891 \mathrm{calBP}$ ( 深 度 $24.71 \sim 24.73 \mathrm{~m}$ ), 46,205〜 
$47,970 \mathrm{calBP}$ (深度 $30.27 \sim 30.29 \mathrm{~m}$ ), 42,340 43,010 cal BP (深度 31.63〜31.65 m) であった．深度 30.27〜 $30.29 \mathrm{~m}$ までの $6 つ の$ 年代值は概ね深度にともない古く なるが，深度 $31.63 \sim 31.65 \mathrm{~m}$ では逆転する。これにつ いては後述する.

\section{VI. 考察}

\section{1. テフラの認定}

3 本のコアから得られたテフラの記載岩石学的特性と 層位関係に基づき，以下のようにテフラを認定し，一部 は産状からその成因についても検討した

\section{沼沢沼沢湖テフラ (Nm-NM)}

AB-12-2 コアの深度 3.59 4.09m より検出された テフラ層は淘汰が良く, 中部に粗粒なラピリや軽石 (最 大粒径 $1 \mathrm{~cm}$ ）を含み基質を欠く特徴をもつことと，地 表に近い層位に位置することから比較的新しい時代に近 傍火山からもたらされた降下テフラと考えられる，その ようなテフラとして Nm-NM があげられ，本研究で模 式地とした福島県金山町大栗山西方の試料とは斑晶鉱物 の組合せ，斜方輝石，ホルンブレンド，火山ガラスの屈 折率，主成分化学組成のいずれもよく類似する (図 5, 表 1)。したがって本テフラは $\mathrm{Nm}-\mathrm{NM}$ と認定できる.

山元 $(1995,2003)$ は，Nm-NM を下位からユニット I〜IV に区分した。このうちユニット II〜IV が降下堆 積物を含むとされ，いずれも会津坂下町周辺での分布が 示されている. しかし本コアで認められたユニットとユ ニット II〜IV との関係は不明である。

\section{姶良 Tn テフラ (AT)}

AB-12-1 コアの深度 14.68 14.72 $\mathrm{m}$ と AB-12-2 コアの深度 17.00〜 $17.05 \mathrm{~m}$ にはともに岩相がよく類似 した白色ガラス質火山灰層が挟在され，火山ガラスの形 状，屈折率，主成分化学組成 (表 1) はいずれも両テフ ラが同一のものであることを示す。そしてそれらの特徴 は, 南九州の姶良カルデラ起源の AT のそれらと一致 し，両テフラはAT と認定できる.

\section{大山倉吉テフラ (DKP)}

AB-12-2 コア, 深度 30.05 30.12 m のガラス質火 山灰層は, 細粒なスポンジ状軽石型火山ガラスと有色鉱 物からなる。 この様な特徵は㯊陵隠岐テフラや御岳第 1 テフラなどプリニー式噴火による降下堆積物の遠隔地の 特徵 (町田・新井, 2003) を示し, 同テフラも遠方火山 のプリニー式噴火に起源をもつと考えられる．斑晶鉱物 の組合せ，斜方輝石の (100) 面の発達, 斜方輝石とホル ンブレンドの屈折率 (表 1)，ATの下位にあることから
本テフラの対比候補は山陰に給源をもち，北関東～東北 南部での分布が知られている大山倉吉テフラ (DKP, 町 田・新井, 1979)である.

陸上産出の DKP の多くは風化により火山ガラスが消 失しており，その屈折率や主成分化学組成の報告は限ら れている.しかし AB-12-2 コア深度 $30 \mathrm{~m}$ 付近に産す る本テフラは火山ガラスが残存し両者の值が得られ た（図 4, 表 1)。古澤・梅田 (2002) は，大山山麓にて DKP と大山関金テフラ (DSP) の火山ガラスの屈折率の 各層内での鉛直方向変化 $(10 \mathrm{~cm}$ 間隔) を明らかにした。 それによる DKP 全層準での火山ガラス屈折率全レンジ は $\mathrm{n}=1.503 \sim 1.512$ ，DSP では層内を 10 層準のうち最 上部の 1 層準が $\mathrm{n}=1.504 \sim 1.514$ であるが，それ以外 は $\mathrm{n}=1.511 〜 1.521$ である. また丸山・齋藤 (2014) は, 富山県西部の砥波平野地下にて火山ガラスが保存された DKP を検出し，火山ガラスの屈折率は，レンジが $\mathrm{n}=$ 1.500 1.516, モードが $\mathrm{n}=1.510$ 前後であると報告し， $\mathrm{n}=1.508 \sim 1.512$ の範囲に 30 測定值のうち 24 測定值 がクラスターをなすことを四示している. AB-12-2 コア 中の本テフラの火山ガラス屈折率 $(\mathrm{n}=1.505 \sim 1.511)$ は，大山山麓と砺波平野地下で得られた DKP と DSP 最上部の火山ガラスの屈折率と類似するといえる (表 1). 一方 DSP について長野県伊那谷で測定された斜方 輝石の屈折率は $\gamma=1.698 \sim 1.705$ (竹本ほか, 1987) で あり, 本テフラ $(\gamma=1.701 \sim 1.708)$ や DKP の值 $(\gamma=$ 1.700 1.711）に比べてやや低い.ささらに大山山麓から 中部地方にかけての DKP と DSP の分布と斜方輝石の 特徵の相違 (町田・新井, 1979) からも, AB-12-2 コア の深度 $30.05 \sim 30.12 \mathrm{~m}$ のテフラは DKP に対比される.

\section{沼沢金山テフラ $(\mathrm{Nm}-\mathrm{KN})$}

AB-12-2 コアの深度 31.10〜31.63 m には，厚く粗 粒（最大粒径 $12 \mathrm{~mm}$ ) な軽石堆積物が先述の DKP に対 比されるテフラの約 $1 \mathrm{~m}$ 下位にある．本層は基質が認 められず淘汰がよく，軽石の円磨度が低く亜角～角砂状 を呈することから降下軽石堆積物と判断できる.

また本テフラはカミングトン閃石を特徵的に含む斑晶 鉱物の組合せとそれらの屈折率，火山ガラスの屈折率と 主成分化学組成 (図 5, 表 1) から, 従来から DKP 直下 に層位をもつ(鈴木・早田，1994）ことが知られている 沼沢カルデラ起源の Nm-KN と一致した特徵をもつ.

これまで Nm-KN は沼沢カルデラから東方にかけて 降下軽石堆積物として分布することが知られており (鈴木・早田, 1994), 山元 (2012) でも本調査地点周辺 で層厚 32〜 64 cm の降下堆積物として分布することが 
報告されている．このような従来から知られた降下堆積 物としての Nm-KN の分布や特徵から AB-12-2 コアの 深度 31.10 31.63 m のテフラは Nm-KN に対比でき る。 また NJUも同様な記載岩石学的特性から $\mathrm{Nm}-\mathrm{KN}$

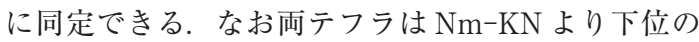
$\mathrm{Nm}-\mathrm{SB}$ と類似した斑晶鉱物組合せをもつが，火山ガラ スの主成分化学組成から明確に識別できる (図 5, 表 1).

\section{赤城追貝テフラ (Ag-OK)}

AB-12-2 コアの深度 36.79 36.82 m で検出された 層厚 $3 \mathrm{~cm}$ の軽石質火山灰層は, 主にスポンジ状軽石型 火山ガラスからなり，先の DKP に対比されたテフラ同 様に，遠方火山のプリニー式噴火に由来すると考えられ る. 両輝石を含む特徴は国内のテフラとしては類例が多 いが，本テフラの対比候補として福島県西部において $\mathrm{Nm}-\mathrm{KN}$ の下位で認定されている赤城追貝テフラ $\left(\mathrm{Ag}^{-}\right.$ OK ; 新井, 1962 ; 鈴木ほか, 1995）があげられる。斑 晶鉱物の組合せと斜方輝石の屈折率, 火山ガラスの屈折 率と主成分化学組成 (図 4, 表 1) が酷似することから両 テフラの対比を示唆する.

\section{田頭テフラ (TG)}

AB-12-2 コアの深度 44.58 45.75 m のテフラおよ びNJLは, 層厚からみて近傍火山起源と考えられる. わずかな黒雲母を除くと有色鉱物をほとんど含まず，低 屈折率の火山ガラスが卓越するなど，砂子原カルデラ起 源テフラの特徴（鈴木ほか，2004）を有する. 同カルデ ラ起源の TG, Sn-MT, Sn-SK について火山ガラスの 主成分化学組成を比較すると, 深度 44.58 45.75 m テ フラおよび $\mathrm{NJL}$ は, $\mathrm{Al}_{2} \mathrm{O}_{3}$ と $\mathrm{CaO}$ の含有量は $\mathrm{TG}$ と似 るが $\mathrm{Sn}-\mathrm{SK}, \mathrm{Sn}-\mathrm{MT}$ より高い。また $\mathrm{K}_{2} \mathrm{O}$ では $\mathrm{Sn}-\mathrm{SK}$ より高く, $\mathrm{FeO}$ が $\mathrm{Sn}-\mathrm{SK}$ より有意に低い (図 5, 表 1). 以上から AB-12-2 コア深度 44.58 45.75 m のテフラ と NJL は TG の特徴と一致するといえ, TGに同定で きる.

ところで中岩田住宅コア地点での TG (層厚 $8.75 \mathrm{~m}$ ) 下部の軽石層は，非火山灰質な下位層と明瞭な境界をな すことと, 軽石の淘汰がよく未円磨であることから降下 軽石堆積物と判断できる。 また上部は礫層に挟まる再堆 積層性のテフラと解釈できる。 これに対して両地点から 約 $6 \mathrm{~km}$ 南方で, 盆地底とは約 $80 \mathrm{~m}$ の比高をもつ丘陵 上の地点 (図 1 の WSAK) に産出する TG は, 上下 2 枚の降下軽石堆積物とそれに挟まる火砕流堆積物と coignimbrite ash fall の組合せからなり全層厚は $43 \mathrm{~cm}$ であり，これと類似する層厚・層相をもつ TG は他に も付近の丘陵基部 2 地点 (図 1 の SKAC と FSP) で確
認されている(鈴木ほか, 2004)。この違いは地形環境 で説明でき, 盆地底という相対的低地に位置する中岩田 住宅・AB-12-2 コア 2 地点では TG 噴火にともなう再 堆積物テフラが厚く堆積し, それよりも地形的に高い丘 陵基部ではその様な影響が少なかったと考えられる。

なお既に述べたように山元 (2012) は会津盆地西縁付 近に TGは分布しないとしており，例えば SKAC 地点 (図 1)の TG を Sn-KB として認定している(鈴木ほか, 2004 ; 山元 ・須藤, 1996). しかし今回 TG の模式試料 を採取したWSAK 地点をはじめ, SKAC や FSP 地点, さらには山元 (2012) が同テフラを認定した福島県南相 馬市塚原海岸において，いずれも火山ガラスの主成分化 学組成や屈折率を根拠に TG が認定されている(鈴木, 1999 ; 鈴木ほか, 2004)。また鈴木ほか (2004) が会津盆 地西縁付近で TG としたテフラを $\mathrm{Sn}-\mathrm{KB}$ とし，その根 拠を $\mathrm{TG} \cdot \mathrm{Sn}-\mathrm{KB}$ 間での斑晶鉱物組合せの相異として いる. しかし山元 (2012) に示されたこれらデータを詳 細にみると，採取地点毎に微妙な違いがあるが，TGで 斜方輝石, 単斜輝石, 黒雲母, ホルンブレンド, カミン グトン閃石，石英が，Sn-KBでも同様な斑晶鉱物組合 せが示されており，斑晶鉱物組合せから TG と $\mathrm{Sn}-\mathrm{KB}$ を識別するのは困難に思われる。 な抢本研究では黒雲母 と石英を除くと他の斑晶鉱物は極めて微量であるので表 1 には示していない

\section{砂子原松ノ下テフラ (Sn-MT)}

AB-12-2 コアの深度 84.91 88.34 m のテフラは厚 層であることから上位の TG 同様に, 会津盆地西縁近傍 の火山に由来すると考えられる，有色鉱物をほとんど含 まない点や低屈折率の火山ガラスを含む点, また火山ガ ラスの主成分化学組成が TG と類似する (図 5, 表 1). しかし本テフラの火山ガラスは, $\mathrm{Al}_{2} \mathrm{O}_{3}$ と $\mathrm{CaO}$ の含有量 が TGのそれらに比べてわずかに低い．従来より TGの 下位には TG と類似したテフラとして上位から Sn-MT と $\mathrm{Sn}-\mathrm{SK}$ の存在が知られ，このうち $\mathrm{Sn}-\mathrm{MT}$ は本地域 より南部の会津盆地西縁付近に损いて産出し, $\mathrm{Al}_{2} \mathrm{O}_{3}$ と $\mathrm{CaO}$ の含有量が TGのそれらに比べてわずかに低いこ とが知られている(鈴木ほか，2004）。こうした特徵か ら本テフラは Sn-MT と考えられる.

Sn-MT は本調查地域南方 5 $6 \mathrm{~km}$ では層厚 $60 \mathrm{~cm}$ の降下灭山灰堆積物 (図 1 の WSAK), あるいは層厚 1.5 $\mathrm{m}$ 以上の火砕流堆積物 (図 1 の FSP) とそれに覆われる 降下テフラとして産出し(山元, 1992 ; 鈴木ほか, 2004), 南西約 $8 \mathrm{~km}$ の給源となる砂子原カルデラ付近でも層厚 $50 \mathrm{~m}$ 以上である塊状の非溶結火砕流堆積物 (山元, 2012 
の $\mathrm{Sn}-\mathrm{KB}$ に相当) からなることが知られている (山元・ 駒澤, 2004). 従来から報告されているこうした Sn-MT の分布からも, $\mathrm{AB}-12-2$ コア中のテフラと $\mathrm{Sn}-\mathrm{MT}$ と の対比は妥当である。

なお AB-12-2 コア中の本テフラの大半を占める上部 （層厚 $3.1 \mathrm{~m}$ ）は，亜角〜角鿬状を呈する白色軽石が散 在し，極粗粒砂サイズの火山灰からなる基質が卓越する ことから火砕流堆積物である可能性が高く，その下位に ある平行葉理をもち淘汰のよい粗粒砂サイズの火山灰層 （層厚 $13 \mathrm{~cm}$ ）は降下火山灰堆積物の可能性がある.

\section{深度 99.25 99.26 m のテフラ}

AB-12-2 コアの最深部付近にある深度 99.25 99.26 $\mathrm{m}$ の白色ガラス質火山灰層は, 上位の TG, Sn-MT 同 様に，有色鉱物をほとんど含まず，低屈折率の火山ガラ スを含む. また火山ガラスの主成分化学組成もそれらと 類似する (図 5，表 1)。したがって層位的に Sn-MT の 下位にあり，上記 2 テフラと類似することが知られてい る Sn-SK に対比される可能性がある. しかし火山ガラ スの主成分化学組成を注意深く比較すると，本テフラの 火山ガラスは Sn-SK のそれらに比べて, わずかに $\mathrm{Al}_{2} \mathrm{O}_{3}$ の含有率が低く, 逆に $\mathrm{CaO}$ と $\mathrm{Na}_{2} \mathrm{O}$ の含有率が高く, 両 テフラを対比することはできない．深度 99.25～99.26 $\mathrm{m}$ にある本テフラはこれまで記載されてないテフラで あり, Sn-SK はより深い深度に存在する可能性がある。

\section{2. テフラの年代}

本調査域における盆地堆積物の堆積速度を考察するた め，今回認定したテフラの年代を検討する. 本研究で認 定したテフラのうち詳細に噴出年代が論じられているも のは, Nm-NM (BC 3,400 年 $=5.4 \mathrm{ka}$; 山元, 2003), AT $(30.009 \pm 0.189 \mathrm{ka}=30 \mathrm{ka}$; Smith et al., 2013),

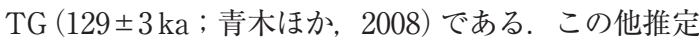
年代值に幅のあるものとして, DKP (> $>55 \mathrm{ka}$; 町田・ 新井，2003 など)， Nm-KN (山元・長谷部，2014によ

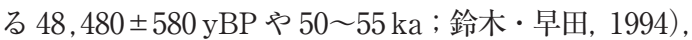
Ag-OK (66〜77 ka；鈴木ほか, 1995), Sn-MT (180〜 $260 \mathrm{ka}$ ；鈴木ほか，2004）がある.

本研究では DKP 直下の ${ }^{14} \mathrm{C}$ 年代値として 46,205 $47,970 \mathrm{cal} \mathrm{BP}$ を得た (試料番号 AB-12-2-F ; 四 3, 表 2). 中村ほか (1992) は DKP の噴出年代を 50 52 ka としており, 本研究による ${ }^{14} \mathrm{C}$ 年代值は中村ほか (1992) の年代值よりも有意に若い，中村ほか (1992) は，DKP 直下の箱根東京テフラ (竹本ほか, 1987) と上位の木曽 川泥流堆積物の ${ }^{14} \mathrm{C}$ 年代值である $52,310 \pm 360 \mathrm{yrs} \mathrm{BP}$

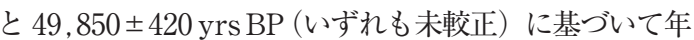

代推定している．本研究による上記の年代值には何らか の問題点がある可能性がある. 今回得た 7 点の ${ }^{14} \mathrm{C}$ 年代 值を検討すると，DKP 層準よりも約 $1.4 \mathrm{~m}$ 下位 $\left(\mathrm{Nm}^{-}\right.$ $\mathrm{KN}$ 直下) から $42,340 \sim 43,010 \mathrm{cal} \mathrm{BP}, 5.6 \mathrm{~m}$ 上位から $42,851 \sim 43,891 \mathrm{cal} \mathrm{BP}$ の ${ }^{14} \mathrm{C}$ 年代值が得られるなど (図 3，表 2)，4万年前を遡る層準では深度に応じた年代值 の増加がなく ${ }^{14} \mathrm{C}$ 年代值が逆転する場合すらあり, ${ }^{14} \mathrm{C}$ 年代值の信頼性が低いことを示唆する。 その原因とし て, 若い炭素の混入により真の年代よりも若くなってい る可能性があげられる。

${ }^{14} \mathrm{C}$ 年代測定法以外の DKP 噴出年代を間接的に示す 年代値として DKP 直下の箱根東京テフラの年代があ る。それらは酸素同位体層序による $66.0 \pm 5.5 \mathrm{ka}$ (青木 ほか，2008）やルミネッセンス法による $67.5 \pm 4.3 \mathrm{ka}$ （Tsukamoto et al., 2010）である. また DKP の噴出年代 の上限を示す年代值として，新潟県津南町にて DKP 上 位の火山灰土より, $62.3 \pm 11 \mathrm{ka}$ と $55.7 \pm 4.0 \mathrm{ka}$ の 2 つ のルミネッセンス年代值が報告されている (Watanuki et al., 2005)。ささらに町田・新井 (2003) は DKP の噴出 年代を中部地方における花粉層序での位置から $55 \mathrm{ka}$ を 遡る可能性を述べた．DKP の噴出年代は今のところ ${ }^{14} \mathrm{C}$ 年代值よりも他の放射年代測定法や酸素同位体層序 による推定法が信頼でき，現段階ではその年代は 55〜 $66 \mathrm{ka}$ と考えられる。

なお，山元・長谷部 (2014) は, DKP 直下の Nm-KN (同論文の $\mathrm{Nm}-\mathrm{MZ}$ ) について, 約 $48 \mathrm{ka} の{ }^{14} \mathrm{C}$ 年代值 （暦年較正前）を報告し, ${ }^{14} \mathrm{C}$ 年代值と暦年較正年代のず れや DKP の噴出年代が 49 53 ka（根拠は DKP の ${ }^{14} \mathrm{C}$ 年代值が 45〜 $48 \mathrm{ka}$ であること) とした上でその噴出年 代を $53 \mathrm{ka}$ とした．本研究では $\mathrm{Nm}-\mathrm{KN}$ 直下より 42 $43 \mathrm{ka}$ の ${ }^{14} \mathrm{C}$ 年代值を得ているが既に述べたようにこの 年代值は ${ }^{14} \mathrm{C}$ 年代の限界に近く信頼性が低い。このよう に $\mathrm{Nm}-\mathrm{KN}$ の噴出年代を ${ }^{14} \mathrm{C}$ 年代から決定することは 困難であると思われる．DKP の噴出年代は既に述べた ように55～66 ka にあると考えられ，層位的関係から は， Nm-KN の噴出年代は 55 66 ka よりも若干遡る と考えられる。

Ag-OK についての推定值である 66〜 77 ka（鈴木ほ か，1995）は，上下の火山灰土中における DKP などと の広域テフラと層位的位置関係から求められたもので あり，基準とした広域テフラの噴出年代值も古い解釈に よるので現段階では信頼性は高くない. Ag-OK は御岳 奈川テフラ (85.1 ka；長橋ほか, 2007) の上位にある

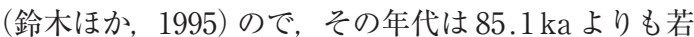




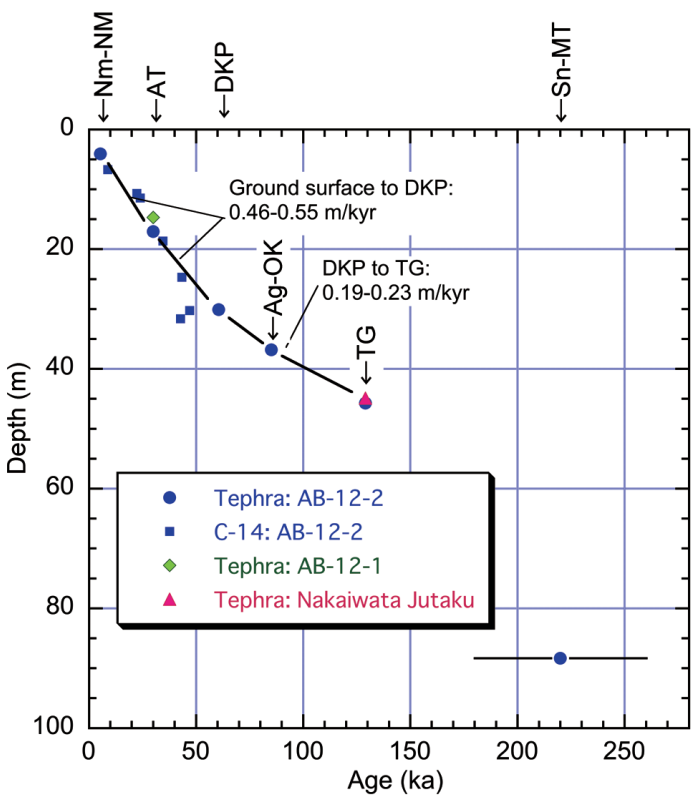

図 6 会津盆地中西部における盆地堆積物の堆積速度

Fig. 6 Accumulation rate of the underground sediments in the middle west part of the Aizu Basin

\section{く，DKPよりも古くなると考えられるにとどまる．}

また，各テフラの噴出年代と深度の関係を図 6 に示 す. TGより下位については Sn-MT の年代推定幅が広 いためここでは言及せず，深度 $44.58 \sim 45.75 \mathrm{~m}$ に産出 する TG 以浅について考察する。

最も古い年代を含む $\mathrm{AB}-12-2$ コアでは, 地表と DKP の深度 $(30.12 \mathrm{~m})$ と年代 (55〜66 ka) から, この 間の堆積速度は $0.46 \sim 0.55 \mathrm{~m} / \mathrm{kyr}$ である．地表/DKP 間では測定限界に近い 2 点の ${ }^{14} \mathrm{C}$ 年代值を除くとこの区 間では平均的には堆積速度はほぼ一定であることが図 6 から読みとれる。

一方, $\mathrm{DKP} / \mathrm{TG}$ 間の堆積速度は $0.20 \sim 0.25 \mathrm{~m} / \mathrm{kyr}$ と地表/DKP 間の $1 / 2$ 以下と小さくなる. この堆積速度 はテフラの層厚を含むが, テフラを除く堆積速度は, 地 表/DKP 間ではテフラの累積層厚が小さいので堆積速 度に大きな違いは生じない.これに対し TGは $117 \mathrm{~cm}$ と厚いので，これを考慮すると堆積速度は 0.19〜0.23 $\mathrm{m} / \mathrm{kyr}$ となり, さらに DKP/TG 間の堆積速度の小ささ が目立つ. 本コアでは, 地表/DKP 間はシルト層, 砂層, 泥炭層からなる細粒堆積物が卓越し砂層が認められない が，DKP/TG 間には薄層ながら礫層（深度 33.69〜 $34.04 \mathrm{~m}$ ) が挟まれる。磁が堆積した環境の有無が堆積
速度に影響を与えた可能性がある.

\section{VII. ま と め}

本研究では会津盆地西部, 会津坂下町で得た 3 本の ボーリングコアから 6 枚のテフラを検出しそれらの認 定を行った。また 7 試料に対する放射性炭素年代測定 を実施した. これらに基づき, 盆地地下堆積物の年代と 深度の関係について論じた. 今後丘陵や盆地地下を構成 する地層のより詳細な観察に基づく層相変化とその年代 や空間分布を把握し, 層相変化と断層活動ないしは古環 境との関連を検討することが課題である. またその際, 本稿で明らかになったテフラの特徵とその層序を基に丘 陵側と盆地地下の地層の比較から, 会津盆.地西縁断層帯 による累積変位量の復元や断層帯の活動史, とくに丘陵 と盆地の分化過程を検討する必要がある.

謝辞 会津坂下町建設部建設班 (現在，教育部教育総 務班) の遠藤幸喜氏には貴重なボーリング試料の御提供 を頂いた．また，ボーリング調査では株式会社サンコア の青野道夫氏にお世話になった。 ここに記して媣く感謝 いたします，本研究におけるボーリング調査は，文部科 学省科研費基盤研究 (A)「変動地形マッピングに基づく 伏在活断層・活褶曲と地震発生様式の解明」(代表者 : 今泉俊文, 課題番号 : 21240074), 同基盤研究 (B)「火山 灰・古地磁気編年による東北日本弧内陸盆地・海岸域に おける第四紀地形発達の研究」(代表者: 鈴木毅彦, 課 題番号：25282082)によった. また本研究の一部は, 著 者の一人である栗山悦宏の首都大学東京大学院都市環境 科学研究科 2011 年度修士論文の一部である.

\section{引 用 文 献}

青木か抢り ・ 入野智久 · 大場忠道 (2008) 鹿島沖海底 コア MD01-2421 の後期更新世テフラ層序. 第四紀 研究, 47, 391-407.

新井房夫（1962）関東盆地北西部地域の第四紀編年.

群馬大学紀要自然科学編, 10, 1-79.

Bronk Ramsey, C. (2009) Bayesian analysis of radiocarbon dates. Radiocarbon, 51, 337-360.

福島県（2000）平成 11 年度地震関係基礎調查交付金会 津盆地西縁断層帯に関する調查成果報告書. $164 \mathrm{p}$, 福島県.

福島県（2001）平成 12 年度地震関係基礎調查交付金会 津盆地西縁断層帯に関する調查成果報告書. $58 \mathrm{p}$, 福 島県. 
福島県（2002）平成 13 年度地震関係基礎調查交付金会 津盆地西縁断層帯に関する調查成果報告書. $82 \mathrm{p}$ ，福 島県.

古澤 明・梅田浩司 (2002) 大山最下部および下部火 山灰にはさまれるテフラの岩石記載的特徵. 第四紀研 究, 41, 413-420.

今泉俊文 (1999) 活断層の分布から見た東北地方の地形 起伏一いくつかの疑問. 月刊地球, 号外 27, 113-117. 地震調査研究推進本部地震調査委員会 (2008) 会津盆 地西縁・東縁断層带の長期評価の一部改訂について. $34 \mathrm{p}$, 地震調査研究推進本部地震調査委員会, http:// www.jishin.go.jp/main/chousa/katsudansou_ pdf/24_aizu-bonchi_2.pdf, 2013 年 12 月 16 日引用.

活断層研究会 (1991) 新編日本の活断層一分布と資料. $437 \mathrm{p}$, 東京大学出版会.

岸清・宮脇理一郎（1996）新潟県柏崎平野周辺に おける鮮新世一更新世の褶曲形成史. 地学雑誌, $105,88-112$.

町田 洋・新井房夫（1979）大山倉吉軽石層一分布の 広域性と第四紀編年上の意義. 地学雑誌, 88, 33-50. 町田 洋・新井房夫 (2003) 新編 火山灰アトラス [日 本列島とその周辺]. $336 \mathrm{p}$, 東京大学出版会.

丸山 正・齋藤 勝 (2014) 富山県南研市法林寺地区 のボーリングコアにおける火山ガラスを含む大山倉吉 テフラ（DKP）の認定とその北陸地域の活断層の活 動性評価における意義. 地質調查研究報告, 65, 1-9. 宮内崇裕 - 今泉俊文・越後智雄 - 後藤秀昭 - 澤 祥 八木浩司 (2004) $1: 25000$ 都市圈活動断層図「若 松」. 国土地理院技術資料 D1-No. 435.

長橋良隆 - 佐藤孝子 - 竹下欣宏 - 田原敬治 - 公文富士夫 （2007）長野県，高野層ボーリングコア（TKN-2004） に挟在する広域テフラ層の層序と編年. 第四紀研究, 46, 305-325.

中村俊夫 - 岡 重文・坂本 亨 (1992) 東京軽石流堆 積物中の炭化木片の加速器質量分析計による放射性炭 素年代. 地質学雑誌, 98，905-908.

Reimer, P.J., Bard, E., Bayliss, A., Beck, J.W., Blackwell, P.G., Bronk Ramsey, C., Buck, C.E., Cheng, H., Edwards, R.L., Friedrich, M., Grootes, P.M., Guilderson, T.P., Haflidason, H., Hajdas, I., Hatte, C., Heaton, T.J., Hoffmann, D.L., Hogg, A.G., Hughen, K.A., Kaiser, K.F., Kromer, B., Manning, S.W., Niu, M., Reimer, R.W., Richards, D.A., Scott, E.M., Southon, J.R., Staff, R.A., Turney, C.S.M. and van der Plicht, J. (2013) IntCal 13 and Marine 13 Radiocarbon Age Calibration Curves 0-50,000 Years cal BP. Radiocarbon, 55, 1869-1887.

Smith, V.C., Staff, R.A., Blockley, S.P.E., Bronk Ramsey, C., Nakagawa, T., Mark, D.F., Takemura, K., Danhara, T. and Suigetsu 2006 Project Members (2013) Identification and correlation of visible tephras in the Lake Suigetsu SG06 sedimentary archive, Japan : Chronostratigraphic markers for synchronising of east Asian/west Pacific Pacific palaeoclimatic records for $150 \mathrm{ka}$. Quaternary Science Reviews, 61, 121-137.

鈴木敬治・真鍋健一・吉田 義（1977）会津盆地にお ける後期新生代層の層位学的研究と会津盆地の発達 史. 地質学論集，14，17-44.

Suzuki, T. (1996) Chemical analysis of volcanic glass by energy dispersive X-ray spectrometry with JEOL JED-2001 and JSM-5200 : analytical procedures and application. Geographical Reports of Tokyo Metropolitan University, 31, 27-36.

鈴木毅彦（1999）福島県太平洋岸, 塚原海岸における 最終間水期最盛期の海進海退過程とその時期降下した テフラについて. 地学雑誌, 108, 216-230.

鈴木毅彦・早田 勉 (1994) 奥会津沼沢火山から約 5 万年前に噴出した沼沢一金山テフラ. 第四紀研究, 33, 233-242.

鈴木毅彦・木村純一 - 早田 勉 -千葉茂樹 - 小荒井衛 新井房夫・吉永秀一郎・高田将志 (1995) 磐梯火山周 辺に分布する広域テフラ. 地学雑誌, 104, 551-560.

鈴木毅彦・藤原 治・檀原 徹 (2004) 東北南部, 会 津地域周辺に打ける中期更新世テフラの層序と編年. 地学䧱誌, 113, 38-61.

Suzuki, T., Kasahara, A., Nishizawa, F. and Saito, H. (2014) Chemical characterization of volcanic glass shards by energy dispersive X-Ray spectrometry with EDAX Genesis APEX2 and JEOL JSM-6390. Geographical Reports of Tokyo Metropolitan University, 49, 1-12.

竹本弘幸・百瀬 貢・平林 潔・ 小林武彦 (1987) 新 期御岳テフラ層の層序と時代一中部日本における編年 上の意義一．第四紀研究，25，337-352.

Tsukamoto, S., Dullerb, G.A.T., Wintleb, A.G. and Frechena, M. (2010) Optical dating of a Japanese marker tephra using plagioclase. Quaternary Geo- 
chronology, 5, 274-278.

Watanuki, T., Murray, A.S. and Tsukamoto, S. (2005) Quartz and polymineral luminescence dating of Japanese loess over the last $0.6 \mathrm{Ma}$ : Comparison with an independent chronology. Earth and Planetary Science Letters, 240, 774-789.

山元孝広（1992）会津盆地，塔寺層の火山性砕屑物か ら見た砂子原カルデラ火山の中期更新世火山活動. 地 質学雑誌，98，855-866.

山元孝広（1995）沼沢火山における火砕流噴火の多様 性：沼沢湖および水沼火砕堆積物の層序. 火山, 40 , 67-81.

山元孝広（1999）福島-栃木地域に分布する 30-10万 年前のプリニー式降下火砕堆積物：沼沢・遂ケ岳・鬼 怒川・砂子原火山を給源とするテフラ群の層序. 地質 調查所月報，50，743-767.

山元孝広（2003）東北日本, 沼沢火山の形成史：噴出 物層序，噴出年代及びマグマ噴出量の再検討。地質調
查研究報告, 54，323-340.

山元孝広 (2012) 福島-栃木地域に扔ける過去約 30 万 年間のテフラの再記載と定量化. 地質調査研究報告, 63, 35-91.

山元孝広・長谷部忠夫 (2014) 福島県只見町叶津の埋 没化石林の放射性炭素年代 : 沼沢火山水沼噴火年代の 再検討．地質学雑誌，120，1-9.

山元孝広・駒澤正夫（2004）宮下地域の地質. 地域地 質研究報告 (5万分の 1 地質図幅), $71 \mathrm{p}$, 産業技術 総合研究所地質調査総合センター.

山元孝広・須藤 茂 (1996) テフラ層序からみた磐梯 火山の噴火活動史．地質調査所月報，47，335-359.

山元孝広・吉岡敏和・牧野雅彦・住田達哉 (2006) 喜 多方地域の地質. 地域地質研究報告 (5 万分の 1 地質 図幅), $63 \mathrm{p}$ ，産業技術総合研究所地質調査総合セン 夕ー.

柳田 誠（1979）阿賀野川中流域の地形発達史．地理 学評論, 52, 689-705.

\title{
Late Quaternary tephrostratigraphy of underground sediments in the middle west part of Aizu Basin, Fukushima, northeast Japan
}

\author{
Takehiko Suzuki*1, a , Haruka Saito*1, Amao Kasahara*1, \\ Etsuhiro Kuriyama*2 and Toshifumi Imaizumi*3
}

Tephra layers were identified from three boring cores in Aizubange Town, middle west part of the Aizu Basin, one of the tectonic basins in the south part of Northeast Japan. Ages of seven horizons were determined by radiocarbon dating. These results clarified the tephrostratigraphy, chronology, and accumulation rates of subsurface sediments in the study area. Sediments with a depth less than $c a .100 \mathrm{~m}$ are mainly composed of silt, peat, and sand with several intercalations of gravel beds and tephra layers. These tephra layers can be correlated with Nm-NM (5.4 ka), AT (30 ka), DKP (55-66 ka), $\mathrm{Nm}-\mathrm{KN}, \mathrm{Ag}-\mathrm{OK}(<85.1 \mathrm{ka})$, TG (129 ka), and SnMT (180-260 ka). Estimated accumulation rates determined for the longest core are $0.46-0.55 \mathrm{~m} /$ kyrs after the deposition of DKP to present, whereas they are $0.19-0.23 \mathrm{~m} / \mathrm{kyr}$ at the depth between the horizons of DKP and TG.

Keywords : boring core, Aira-Tn tephra, Daisen-Kurayoshi tephra, Numazawa Kanayama tephra, Tagashira tephra

*1 Department of Geography, Tokyo Metropolitan University. 1-1 Minamiosawa, Hachioji, Tokyo, 192-0397, Japan.

*2 Japan Aerospace Exploration Agency. 7-44-1 Jindaiji-higashimachi, Chofu, Tokyo, 182-8522, Japan.

*3 Department of Geoscience, Tohoku University. 6-3 Aoba, Aramaki, Aoba-ku, Sendai, Miyagi, 980-8578, Japan.

*a Corresponding author : suzukit@tmu.ac.jp 